Organozi r coni um Compl ex wi th Keggi n- type Mono- al umi numsubst i t ut ed Si I i cot ungst at e : Synt hesi s, Mol ecul ar St ruct ure, and Cat al yt i c Perf or mance for Meer wei $n$ - Ponndor $f$-Ver I ey Reduct i on

\begin{tabular}{|c|c|}
\hline 著者 & $\begin{array}{l}\text { Kat o Chi ka Nozaki, Unno Wat ar u, Kat o Saki e, } \\
\text { Ogasawar a Tsukasa, Kashi wagi Toshi f umi, Uno } \\
\text { Hi dem t su, Suzuki Kosuke, M zuno Nori taka }\end{array}$ \\
\hline $\begin{array}{l}\mathrm{j} \text { our nal or } \\
\text { publ i cat } \mathrm{i} \text { on } \mathrm{titl} \text { e }\end{array}$ & Cat al ysi s Let ters \\
\hline vol une & 146 \\
\hline nunber & 10 \\
\hline page $r$ ange & 2119- 2128 \\
\hline year & 2016-07- 23 \\
\hline 出版者 & Spr i nger US \\
\hline 権利 & $\begin{array}{l}\text { (C) Spri nger Sci ence+Busi ness Medi a New York } \\
2016\end{array}$ \\
\hline 注記 & $\begin{array}{l}\text { The fi nal publ i cat i on is avai I able at Spr i nger } \\
\text { vi a } \\
\text { ht t p: //dx. doi . or g/10. 1007/s10562-016-1813- } 7\end{array}$ \\
\hline URL & ht t p: //hdl . handl e. net /10297/10352 \\
\hline
\end{tabular}




\title{
Organozirconium Complex with Keggin-type Mono-aluminum- substituted Silicotungstate: Synthesis, Molecular Structure, and Catalytic Performance for Meerwein-Ponndorf-Verley Reduction
}

\author{
Chika Nozaki Kato • Wataru Unno • Sakie Kato • Tsukasa Ogasawara • Toshifumi \\ Kashiwagi • Hidemitsu Uno • Kosuke Suzuki • Noritaka Mizuno
}

C. N. Kato (corresponding author) • W. Unno • S. Kato $\bullet$ T. Ogasawara $\bullet$ T. Kashiwagi Department of Chemistry, Faculty of Science, Shizuoka University, 836 Ohya, Suruga-ku, Shizuoka 422-8529, Japan

e-mail: sckatou@ipc.shizuoka.ac.jp (C. N. Kato)

C. N. Kato

Green Chemistry Research Division, Research Institute of Green Science and Technology, Shizuoka University, 836 Ohya, Suruga-ku, Shizuoka 422-8529, Japan

H. Uno

Department of Chemistry and Biology, Graduate School of Science and Engineering, Ehime University, Matsuyama, 790-8577, Japan

K. Suzuki • N. Mizuno

Department of Applied Chemistry, School of Engineering, The University of Tokyo, 7-3-1 Hongo, Bunkyo-ku, Tokyo, 113-8656, Japan 
Abstract: The organozirconium complex with $\alpha$-Keggin-type mono-aluminum-substituted silicotungstate, $\quad\left[\left(n-\mathrm{C}_{4} \mathrm{H}_{9}\right)_{4} \mathrm{~N}\right]_{6}\left[\alpha-\mathrm{SiW}_{11} \mathrm{Al}(\mathrm{OH})_{2} \mathrm{O}_{38} \mathrm{ZrCp}_{2}\right]_{2} \cdot 2 \mathrm{H}_{2} \mathrm{O} \quad$ (TBA-Si-Al-Zr) was synthesized by the reaction of $\mathrm{Cp}_{2} \mathrm{Zr}(\mathrm{OTf})_{2} \cdot \mathrm{THF}$ (or $\left.\mathrm{Cp}_{2} \mathrm{ZrCl}_{2}\right)$ with $\left[\left(n-\mathrm{C}_{4} \mathrm{H}_{9}\right)_{4} \mathrm{~N}_{4} \mathrm{~K}_{0.5} \mathrm{H}_{0.5}[\alpha-\right.$ $\left.\mathrm{SiW}_{11}\left\{\mathrm{Al}\left(\mathrm{OH}_{2}\right)\right\} \mathrm{O}_{39}\right] \cdot \mathrm{H}_{2} \mathrm{O}$ in acetonitrile. This compound showed high catalytic activities for Meerwein-Ponndorf-Verley reduction of ketones with 2-propanol in both homogeneous and heterogeneous system.

\section{Graphical Abstract}

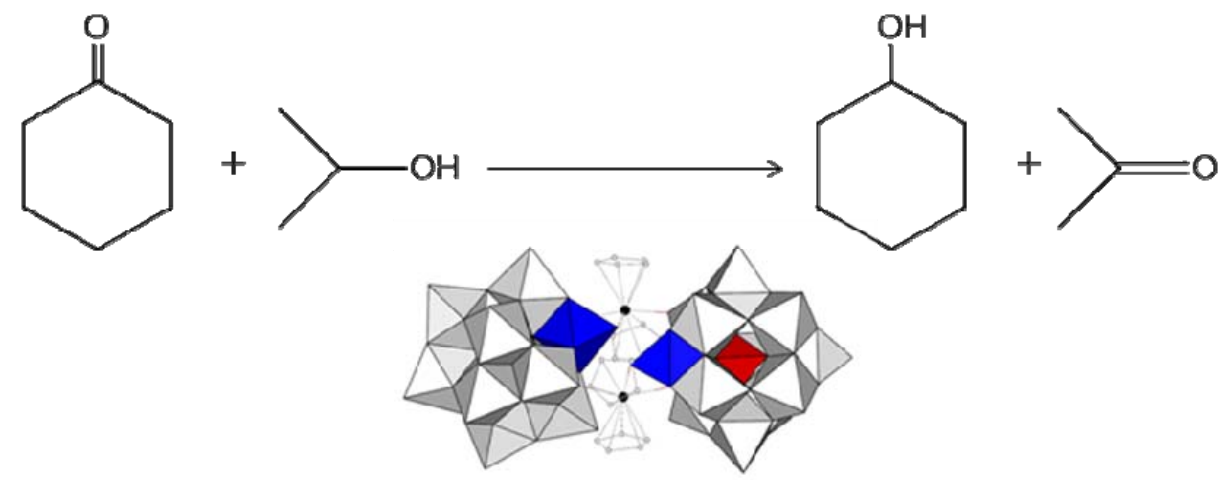

Keywords Organozirconium complex - Polyoxometalate • X-Ray crystal structure • Meerwein-Ponndorf-Verley reduction • Heterogeneous catalyst

\section{Introduction}

Polyoxometalates (POMs) are discrete anionic metal-oxygen clusters that can be regarded as soluble oxide fragments. They have attracted substantial attention in the fields of catalysis, surface science, and materials science because of their chemical properties, including their redox potentials, acidities, and solubilities in various media, which can be finely tuned by choosing the appropriate constituent elements and countercations. In particular, the coordination of metal ions to the vacant site(s) of lacunary POMs is one of the most effective techniques for constructing efficient and well-defined active metal centers [1-4].

Several strategies for expanding POM chemistry have been considered, and covalent 
grafting reactions of organic/organometallic fragments onto the surfaces of POMs has been presented as an effective technique to functionalize POM-based materials [5-7]. For grafting reactions, complete (plenary) POMs obtained by the substitution of $d^{0}$ transition metals or reduction [5-16] and lacunary POM ligands [5-7, 17-24] have been used as supports, and numerous organic-inorganic hybrid materials have been applied to catalysts and functionalized materials. Thus, the development of polyoxoanion-supported organic/organometallic compounds has great potential to further expand POM chemistry.

To explore POMs that could be used as supports for grafting reactions, we focused on the aluminum-substituted POMs and successfully synthesized an organozirconium(IV)-supported polyoxometalate, $\left[\alpha-\mathrm{PW}_{11} \mathrm{Al}(\mathrm{OH}) \mathrm{O}_{39} \mathrm{ZrCp}_{2}\right]_{2}{ }^{6-}\left(\mathrm{Cp}=\eta^{5}-\mathrm{C}_{5} \mathrm{H}_{5}{ }^{-}\right)$(P-Al-Zr), by a grafting reaction of $\alpha$-Keggin mono-aluminum-substituted phosphotungstate with a bis $\left(\eta^{5}\right.$ cyclopentadienyl)zirconium(IV) fragment [25]. Although the chemistry of organometallic moieties possessing $\eta^{5}$-cyclopentadienyl ligands has rapidly expanded [26-28], new studies on their grafting reactions onto POM surfaces have not been conducted: some examples (determined by X-ray analysis) include $\left\{\left[\mathrm{Cp}_{2} \mathrm{U}_{2}\left(\mu-\kappa^{2} \mathrm{O}-\mathrm{TiW}_{5} \mathrm{O}_{19}\right)_{2}\right\}^{4-} \quad[29,30]\right.$, $\left[\left(\mathrm{PW}_{11} \mathrm{O}_{39} \mathrm{NbO}\right)_{2} \mathrm{ZrCp}_{2}\right]^{6-} \quad[31,32], \quad\left[\mathrm{CpTiW}_{5} \mathrm{O}_{18}\right]^{3-} \quad[33], \quad\left[\mathrm{Cp}_{3} \mathrm{U}_{\left.\left(\mathrm{MW}_{5} \mathrm{O}_{19}\right)_{2}\right]^{5-}, \quad \text { and }}\right.$ $\left[\mathrm{Cp}_{3} \mathrm{Th}\left(\mathrm{MW}_{5} \mathrm{O}_{19}\right)_{2}\right]^{5-}(\mathrm{M}=\mathrm{Nb}, \mathrm{Ta})[34]$.

In this study, we focused on the use of the tetra- $n$-butylammonium/potassium salt of $\alpha$ Keggin mono-aluminum-substituted silicotungstate, $\quad\left[\left(n-\mathrm{C}_{4} \mathrm{H}_{9}\right){ }_{4} \mathrm{~N}\right]{ }_{4} \mathrm{~K}_{0.5} \mathrm{H}_{0.5}[\alpha-$ $\left.\mathrm{SiW}_{11}\left\{\mathrm{Al}\left(\mathrm{OH}_{2}\right)\right\} \mathrm{O}_{39}\right] \cdot \mathrm{H}_{2} \mathrm{O}$ (TBA-Si-Al), as a support and synthesized the tetra- $n$ butylammonium salt of the organozirconium(IV) compound, $\quad\left[\left(n-\mathrm{C}_{4} \mathrm{H}_{9}\right)_{4} \mathrm{~N}\right]_{6}[\alpha-$ $\left.\mathrm{SiW}_{11} \mathrm{Al}(\mathrm{OH})_{2} \mathrm{O}_{38} \mathrm{ZrCp} 2\right]_{2} \cdot 2 \mathrm{H}_{2} \mathrm{O}$ (TBA-Si-Al-Zr). The compound TBA-Si-Al-Zr was characterized by X-ray crystallography, elemental analysis, TG/DTA, potentiometric titration, FTIR, cold-spray ionization mass (CSI-MS), and solution $\left({ }^{27} \mathrm{Al},{ }^{1} \mathrm{H}\right.$, and $\left.{ }^{13} \mathrm{C}\right)$ and solid-state $\left({ }^{27} \mathrm{Al},{ }^{13} \mathrm{C}\right.$, and $\left.{ }^{29} \mathrm{Si}\right) \mathrm{NMR}$ spectroscopy. Furthermore, TBA-Si-Al-Zr and $\left[\left(n-\mathrm{C}_{4} \mathrm{H}_{9}\right)_{4} \mathrm{~N}\right] 6[\alpha-$ $\left.\mathrm{PW}_{11} \mathrm{Al}(\mathrm{OH}) \mathrm{O}_{39} \mathrm{ZrCp}_{2}\right]_{2}$ (TBA-P-Al-Zr) were used as homogeneous and heterogeneous catalysts in the Meerwein-Ponndorf-Verley (MPV) reduction of cyclohexanone, 2-hexanone, and cyclopentanone with 2-propanol. Herein, we report the complete details of the synthesis 
and molecular structure of complex Si-Al-Zr and demonstrate the catalytic activities of the $\operatorname{bis}\left(\eta^{5}\right.$-cyclopentadienyl)zirconium(IV) complexes with $\alpha$-Keggin mono-aluminumsubstituted polyoxotungstates.

\section{Experimental}

\subsection{Materials}

$\mathrm{K}_{8}\left[\alpha-\mathrm{SiW}_{11} \mathrm{O}_{39}\right] \cdot 12 \mathrm{H}_{2} \mathrm{O}$ was synthesized according to the literature [35]. [(n$\left.\left.\mathrm{C}_{4} \mathrm{H}_{9}\right)_{4} \mathrm{~N}\right] 4 \mathrm{~K}_{0.5} \mathrm{H}_{0.5}\left[\alpha-\mathrm{SiW}_{11}\left\{\mathrm{Al}\left(\mathrm{OH}_{2}\right)\right\} \mathrm{O}_{39}\right] \cdot \mathrm{H}_{2} \mathrm{O}$ (TBA-Si-Al) was synthesized by a published method with modifications [36]. The synthesis and characterization results of TBA-Si-Al are shown in the Supporting Information. $\mathrm{H}_{3} \mathrm{PW}_{12} \mathrm{O}_{40} \cdot 23 \mathrm{H}_{2} \mathrm{O}$ was obtained from Nippon Inorganic Colour \& Chemical Co., Ltd (Japan). The number of solvated water molecules in these compounds was determined by TG/DTA analysis. TBA-P-Al, TBA-P-Al-Zr, and $\mathrm{Cp}_{2} \mathrm{Zr}(\mathrm{OTf})_{2} \cdot \mathrm{THF}\left(\mathrm{OTf}=\mathrm{CF}_{3} \mathrm{SO}_{3}{ }^{-}\right)$were synthesized by previously published methods [25,37]. All the reagents and solvents were obtained and used as received from commercial sources. Acetonitrile (containing $\leq 0.001 \%$ water) was used for the synthesis of TBA-Si-AlZr.

\subsection{Instrumentation/Analytical Procedures}

Elemental analysis was performed using a Mikroanalytisches Labor Pascher (Remagen, Germany) instrument. The samples were dried overnight at room temperature under $10^{-3}$ $10^{-4}$ Torr vacuum before analysis. Infrared spectra were recorded on a Perkin Elmer Spectrum 100 FT-IR spectrometer, in $\mathrm{KBr}$ disks, at room temperature. Thermogravimetric (TG) and differential thermal analysis (DTA) data were obtained using a Rigaku Thermo Plus 2 series TG/DTA TG 8120. TG/DTA measurements were performed in air while increasing the temperature by $4{ }^{\circ} \mathrm{C}$ per min from 20 to $500{ }^{\circ} \mathrm{C}$. Solution ${ }^{1} \mathrm{H}(600.17 \mathrm{MHz}),{ }^{13} \mathrm{C}(150.92 \mathrm{MHz})$, 
${ }^{31} \mathrm{P}-\left\{{ }^{1} \mathrm{H}\right\} \quad(242.95 \mathrm{MHz}),{ }^{29} \mathrm{Si}(119.23 \mathrm{MHz})$, and ${ }^{27} \mathrm{Al} \mathrm{NMR}(156.36 \mathrm{MHz})$ spectra were recorded in 5-mm-outer diameter tubes on a JEOL ECA-600 NMR spectrometer. ${ }^{1} \mathrm{H}$ and ${ }^{13} \mathrm{C}$ NMR spectra were measured in acetonitrile- $d_{3}$ with reference to tetramethylsilane (TMS). Chemical shifts are reported as positive for resonances downfield of TMS $(\delta 0)$. The ${ }^{31} \mathrm{P},{ }^{29} \mathrm{Si}$, and ${ }^{27} \mathrm{Al}$ NMR spectra were measured in acetonitrile- $d_{3}$ with reference to an external standard (a substitution method) of $85 \% \mathrm{H}_{3} \mathrm{PO}_{4}$ in a sealed capillary, TMS, and a saturated $\mathrm{AlCl}_{3}-\mathrm{D}_{2} \mathrm{O}$ solution, respectively. Chemical shifts for ${ }^{31} \mathrm{P}$ and ${ }^{29} \mathrm{Si}$ NMR spectra were reported as negative on the $\delta$ scale for resonances upfield of $\mathrm{H}_{3} \mathrm{PO}_{4}(\delta 0)$ and TMS $(\delta 0)$. The chemical shifts in the ${ }^{27} \mathrm{Al} \mathrm{NMR}$ spectra were reported as positive on the $\delta$ scale for resonances downfield of $\mathrm{AlCl}_{3}\left(\begin{array}{l}\delta \\ 0\end{array}\right)$. When a quartz tube was used for ${ }^{27} \mathrm{Al}$ NMR spectroscopy, a background signal was also observed in the spectrum. Solid-state ${ }^{27} \mathrm{Al},{ }^{13} \mathrm{C}$, and ${ }^{29} \mathrm{Si} \mathrm{NMR}$ spectra were recorded at $400 \mathrm{MHz}$ on a JEOL JNM-ECA 400 FT-NMR spectrometer with a JEOL ECP-400 NMR data-processing system. The chemical shifts $\delta$ for ${ }^{27} \mathrm{Al}$ and ${ }^{13} \mathrm{C} \mathrm{NMR}$ spectra were reported to be positive on the $\delta$ scale for resonances upfield of $\mathrm{AlCl}_{3}(\delta 0)$ and the methyl group of $\mathrm{C}_{6}\left(\mathrm{CH}_{3}\right)_{6}(\delta 17.4)$. The ${ }^{29} \mathrm{Si}$ NMR chemical shifts are reported as negative relative to polydimethylsilane $(\delta-31.0)$. Cold-spray ionization mass spectra (CSI-MS) were recorded on a JEOL JMS-T100CS (acetonitrile, $1 \mathrm{mg} / \mathrm{mL}$; spray temperature, $-20^{\circ} \mathrm{C}$ ) at The University of Tokyo. Potentiometric titration was carried out with $0.010 \mathrm{~mol} / \mathrm{L}$ tetra- $n$ butylammonium hydroxide as a titrant under Ar atmosphere [38]. The compound TBA-Si-Al$\mathrm{Zr}(0.010 \mathrm{mmol})$ was dissolved in acetonitrile $(20 \mathrm{~mL})$ at $25{ }^{\circ} \mathrm{C}$, and the solution was stirred for approximately $5 \mathrm{~min}$. The titration data were obtained with a $\mathrm{pH}$ meter (Mettler Toledo). Data points were obtained in millivolt. A solution of tetra- $n$-butylammonium hydroxide $(0.010 \mathrm{~mol} / \mathrm{L})$ was syringed into the suspension in 0.10 -equivalent intervals.

\subsection{Synthesis of $\left[\left(n-\mathrm{C}_{4} \mathrm{H}_{9}\right)_{4} \mathrm{~N}\right]_{6}\left[\alpha-\mathrm{SiW}_{11} \mathrm{Al}(\mathrm{OH})_{2} \mathrm{O}_{38} \mathrm{ZrCp}_{2}\right]_{2} \cdot 2 \mathrm{H}_{2} \mathrm{O}$ (TBA-Si-Al-Zr)}

The following manipulations were performed in a dry box filled with Ar ( $>99.9995$ vol\% purity). A solution of $\mathrm{Cp}_{2} \mathrm{Zr}(\mathrm{OTf})_{2} \cdot \mathrm{THF}(0.327 \mathrm{~g} ; 0.54 \mathrm{mmol})$ dissolved in $10 \mathrm{~mL}$ of 
acetonitrile was slowly added to a solution of TBA-Si-Al (2.0 g; $0.54 \mathrm{mmol})$ dissolved in 15 $\mathrm{mL}$ of acetonitrile. The color of the solution changed to yellow. After stirring for $4 \mathrm{~h}$ at $25^{\circ} \mathrm{C}$, the mixed solution was filtered through a folded filter paper (Whatman \#5). At this stage, the filtrate was removed from the dry box, and combined with water $(400 \mathrm{~mL})$ under ambient atmosphere. The yellow-white precipitate was collected using a membrane filter (JG $0.2 \mu \mathrm{m})$ and washed with a small amount of ethanol. The yield of the crude product was $1.721 \mathrm{~g}$. The crude product $(1.721 \mathrm{~g})$ was dissolved in acetonitrile $(34 \mathrm{~mL})$ and then filtered through a folded filter paper (Whatman \#5). The yellow platelet crystals were obtained by vapor diffusion from methanol in air. The yield of the product was $0.836 \mathrm{~g}$ (the percentage yield of 21.3\% was calculated based on the following: 2[moles of TBA-Si-Al-Zr]/[moles of TBA-SiAl] $\times 100)$. Elemental analysis results showed: $\mathrm{C}, 19.02, \mathrm{H}, 3.30 ; \mathrm{Al}, 0.79 ; \mathrm{N}, 1.15 ; \mathrm{Si}, 0.75$; W, 54.50; Zr, $2.45 ; \quad \mathrm{K} \quad<0.01 \%$. Calculations for $\left[\left(n-\mathrm{C}_{4} \mathrm{H}_{9}\right)_{4} \mathrm{~N}\right]_{6}[\alpha-$ $\left.\mathrm{SiW}_{11} \mathrm{Al}(\mathrm{OH})_{2} \mathrm{O}_{38} \mathrm{ZrCp}_{2}\right]_{2} \cdot 2 \mathrm{H}_{2} \mathrm{O}=\mathrm{C}_{116} \mathrm{H}_{244} \mathrm{Al}_{2} \mathrm{~N}_{6} \mathrm{O}_{82} \mathrm{Si}_{2} \mathrm{~W}_{22} \mathrm{Zr}_{2}$ (7372.267): C, 18.90, H, 3.34; Al, 0.73; N, 1.14; Si, 0.76; W, 54.86; Zr, 2.47; K $0 \%$. A weight loss of $0.18 \%$ was observed during drying overnight at room temperature, under a vacuum of $10^{-3}-10^{-4}$ Torr prior to analysis, suggesting the removal of weakly solvated or adsorbed acetonitrile molecules; this was also supported by the absence of any signal attributable to acetonitrile molecules in the ${ }^{1} \mathrm{H}$ NMR spectrum of the sample acquired in DMSO- $d_{6}$ after drying overnight. TG/DTA performed under atmospheric conditions showed a weight loss of $24.74 \%$ with exothermic points at 352.0 and $483.0{ }^{\circ} \mathrm{C}$ (observed below $500{ }^{\circ} \mathrm{C}$ ). No clear endothermic point was observed. The calculated weight loss of $25.4 \%$ was consistent with the loss of four Cp ligands, six tetra- $n$-butylammonium ions, and two water molecules. IR ( $\mathrm{KBr}$ disk) in the $1300-400$ $\mathrm{cm}^{-1}$ region (polyoxometalate region): $1012 \mathrm{~s}, 969 \mathrm{~s}, 921 \mathrm{~s}, 885 \mathrm{~s}, 799 \mathrm{~s}, 756 \mathrm{~s}, 733 \mathrm{~s}$, and 669 $\mathrm{m} \mathrm{cm}^{-1}$. Solution NMR results gave ${ }^{1} \mathrm{H}$ NMR $\left(\mathrm{CD}_{3} \mathrm{CN}, 25.4{ }^{\circ} \mathrm{C}\right): \delta 6.69$ (singlet) $(\mathrm{Cp}), 6.64$ (singlet) (Cp), 6.63 (singlet) (Cp), 6.59 (singlet) (Cp), 3.16 (triplet), 1.65 (multiplet), 1.42 (multiplet), 1.00 (triplet) $\left(\left[\left(n-\mathrm{C}_{4} \mathrm{H}_{9}\right){ }_{4} \mathrm{~N}\right]^{+}\right)$, and 2.15 (singlet) $\left(\mathrm{H}_{2} \mathrm{O}\right) ;{ }^{13} \mathrm{C} \mathrm{NMR}\left(\mathrm{CD}_{3} \mathrm{CN}, 26.7\right.$ $\left.{ }^{\circ} \mathrm{C}\right): \delta 117.1(\mathrm{Cp}), 117.0(\mathrm{Cp}), 116.8(\mathrm{Cp}), 116.5(\mathrm{Cp}), 59.44,24.51,20.48$, and $14.04([(n-$ $\left.\left.\left.\mathrm{C}_{4} \mathrm{H} 9\right)_{4} \mathrm{~N}\right]^{+}\right) ;{ }^{27} \mathrm{Al}$ NMR $\left(\mathrm{CD}_{3} \mathrm{CN}, 21.9^{\circ} \mathrm{C}\right): \delta$ 15.5. Solid NMR results gave ${ }^{13} \mathrm{C}$ NMR: 
$\delta 116.2$ (singlet) $(\mathrm{Cp}), 58.6,24.8,20.5$, and $\left.14.8\left(\left[\left(n-\mathrm{C}_{4} \mathrm{H} 9\right) 4 \mathrm{~N}\right]\right]^{+}\right) ;{ }^{27} \mathrm{Al} \mathrm{NMR}: \delta 9.84 ;{ }^{29} \mathrm{Si}$ NMR: $\delta$-81.9. Positive ion CSI-MS $\left(\mathrm{CH}_{3} \mathrm{CN}, 253 \mathrm{~K}\right) \mathrm{m} / \mathrm{z} 3910.8$ and 7577.4 (calcd $\mathrm{m} / \mathrm{z}$ $3910.4 \quad\left[\left\{\left(n-\mathrm{C}_{4} \mathrm{H}_{9}\right)_{4} \mathrm{~N}\right\} 8{ }_{8}\left\{\mathrm{SiW}_{11} \mathrm{Al}(\mathrm{OH})_{2} \mathrm{O}_{38} \mathrm{ZrCp}_{2}\right\}_{2}\right]^{2+}$ and $7577.4 \quad[\{(n-$ $\left.\left.\left.\left.\mathrm{C}_{4} \mathrm{H}_{9}\right)_{4} \mathrm{~N}\right\}{ }_{7}\left\{\mathrm{SiW}_{11} \mathrm{Al}(\mathrm{OH})_{2} \mathrm{O}_{38} \mathrm{ZrCp}_{2}\right\}_{2}\right]^{+}\right)$.

\subsection{X-ray crystallography}

A yellow platelet-shaped crystal of TBA-Si-Al-Zr $(0.140 \times 0.090 \times 0.040 \mathrm{~mm})$ was mounted on a MicroMount. Data were collected on a Rigaku VariMax instrument with Saturn connected to a multi-layer mirror using monochromated Mo Ka radiation $(\lambda=0.71075 \AA)$ at $154 \pm 1$ K. Data were collected and processed using the CrystalClear for Windows software. The structural analysis was performed using the CrystalStructure for Windows software. The structure was solved using SHELXS-97 (direct methods) and refined using SHELXL-97 [39]. For the polyoxoanion Si-Al-Zr, $22 \mathrm{~W}$ atoms, $2 \mathrm{Zr}$ atoms, $2 \mathrm{Si}$ atoms, $2 \mathrm{Al}$ atoms, and $80 \mathrm{O}$ atoms were clearly identified, thereby clarifying the main features of the molecular structure of the polyoxometalate. The six tetra-n-butylammonium ions and two water molecules could not be modeled with disordered atoms. Accordingly, the residual electron density was removed using the SQUEEZE routine in PLATON [40].

\subsection{Crystal data for TBA-Si-Al-Zr}

$\mathrm{C}_{116} \mathrm{H}_{244} \mathrm{Al}_{2} \mathrm{~N}_{6} \mathrm{O}_{82} \mathrm{Si}_{2} \mathrm{~W}_{22} \mathrm{Zr}_{2} ; \mathrm{M}=7372.47$, monoclinic, space group $C 2 / c$ (\#15), $a=$ 25.252(8), $b=17.619(6), c=46.77(2) \AA, V=20807(11) \AA^{3}, Z=4, D_{\mathrm{c}}=2.353 \mathrm{~g} / \mathrm{cm}^{3}, \mu(\mathrm{Mo}-$ $\mathrm{K} \alpha) 123.080 \mathrm{~cm}^{-1} \cdot R_{1}=0.0721(I>2 \sigma(I)), \mathrm{w} R_{2}=0.2308$ (for all data). GOF $=1.126(100607$ total reflections, 21524 unique reflections where $I>2 \sigma(I))$. Some acetonitrile molecules were observed in a single crystal of TBA-Si-Al-Zr; however, no acetonitrile solvent molecules were observed by elemental analysis or ${ }^{1} \mathrm{H}$ NMR spectroscopy. Thus, the solvent molecules evaporate gradually when crystals are removed from acetonitrile solution. CCDC reference 
number 967942. The data for TBA-Si-Al-Zr can be obtained free of charge at www.ccdc.cam.ac.uk/conts/retrieving.html [or from Cambridge Crystallographic Data Centre, 12 Union Road, Cambridge CB2 1EZ, UK; Fax: +44-1223-336-033; E-mail: deposite@,ccdc.cam.ac.uk.]

\subsection{MPV reduction}

For the MPV reduction of cyclohexanone with 2-propanol in a homogeneous system, a sample catalyst was placed in a $60 \mathrm{~mL}$ Schlenk tube under Ar atmosphere. Cyclohexanone (1.9 mmol), 2-propanol (13 mmol), and acetonitrile (4 mL) were added using a micropipette. In a heterogeneous system, a mixture of catalyst, ketones (cyclohexanone, cyclopentanone, and 2-hexanone; 1.6 - $2.2 \mathrm{mmol}$ ), and 2-propanol (78 mmol) was placed in a Schlenk tube under Ar atmosphere. The reaction mixture was heated in an oil bath at $80 \pm 2{ }^{\circ} \mathrm{C}$. The reaction solution was analyzed by gas chromatography (flame ionization detector, a capillary column DB-WAX, $0.53 \mathrm{~mm} \times 15 \mathrm{~m}$ and a glass column BX-10, $3.2 \mathrm{~mm} \times 3 \mathrm{~m}$ ) and ${ }^{1} \mathrm{H} \mathrm{NMR}$ spectroscopy. Values of the products were assigned by comparing the obtained results with the analysis results obtained from analyzing the authentic samples under the same conditions. The conversion $(\%)$ and turnover number $(\mathrm{TON})$ was calculated as $\left\{[\mathrm{mol} \text { of substrate }]_{0}-\right.$ $\left.[\mathrm{mol} \text { of substrate }]_{t}\right\} /[\mathrm{mol} \text { of substrate }]_{0} \times 100$ and [mol of corresponding alcohol $]_{t} /[\mathrm{mol}$ of catalyst], respectively.

\section{Results and Discussion}

3.1 Synthesis and molecular structure of $\left[\left(n-\mathrm{C}_{4} \mathrm{H}_{9}\right)_{4} \mathrm{~N}\right]_{6}\left[\alpha-\mathrm{SiW}_{11} \mathrm{Al}(\mathrm{OH})_{2} \mathrm{O}_{38} \mathrm{ZrCp}_{2}\right]_{2} \cdot 2 \mathrm{H}_{2} \mathrm{O}$ (TBA-Si-Al-Zr)

The $\operatorname{bis}\left(\eta^{5}\right.$-cyclopentadienyl)zirconium(IV) compound with $\alpha$-Keggin mono-aluminumsubstituted silicotungstate Si-Al-Zr was obtained in $21.3 \%$ yield based on the tetra- $n$ - 
butylammonium salt $\left[\left(n-\mathrm{C}_{4} \mathrm{H}_{9}\right)_{4} \mathrm{~N}\right] 6\left[\alpha-\mathrm{SiW}_{11} \mathrm{Al}(\mathrm{OH})_{2} \mathrm{O}_{38} \mathrm{ZrCp}_{2}\right]_{2} \cdot 2 \mathrm{H}_{2} \mathrm{O}$ (TBA-Si-Al-Zr). This compound was prepared by the 1:1 stoichiometric reaction of $\left[\left(n-\mathrm{C}_{4} \mathrm{H}_{9}\right)_{4} \mathrm{~N}_{4} \mathrm{~K}_{0.5} \mathrm{H}_{0.5}[\alpha-\right.$ $\left.\mathrm{SiW}_{11}\left\{\mathrm{Al}\left(\mathrm{OH}_{2}\right)\right\} \mathrm{O}_{39}\right] \cdot \mathrm{H}_{2} \mathrm{O}$ (TBA-Si-Al) with $\mathrm{Cp}_{2} \mathrm{Zr}(\mathrm{OTf})_{2} \cdot \mathrm{THF}$ in acetonitrile under an $\mathrm{Ar}$ atmosphere, followed by precipitation from water under ambient atmosphere. Finally, yellow crystalline products were obtained by crystallization via vapor diffusion from acetonitrile/methanol at $25{ }^{\circ} \mathrm{C}$ in air. When $\mathrm{Cp}_{2} \mathrm{Zr}(\mathrm{OTf})_{2} \cdot \mathrm{THF}$ was added to the acetonitrile solution of $\mathrm{H}_{3} \mathrm{PW}_{12} \mathrm{O}_{40} \cdot 23 \mathrm{H}_{2} \mathrm{O}$, a white precipitate formed and it was insoluble in acetonitrile. It was noted that polyoxoanion Si-Al-Zr was formed by the direct reaction of TBA-Si-Al with $\mathrm{Cp}_{2} \mathrm{ZrCl}_{2}$ in air, whereas the polyoxoanion $\mathbf{P}-\mathbf{A l}-\mathbf{Z r}$ was not obtained by a direct reaction of $\left[\alpha-\mathrm{PW}_{11}\left\{\mathrm{Al}\left(\mathrm{OH}_{2}\right)\right\} \mathrm{O}_{39}\right]^{4-}$ (P-Al) with zirconocene dichloride. In addition, single crystals suitable for X-ray crystallography of TBA-Si-Al-Zr were quite stable toward moisture; in contrast, the quality of TBA-P-Al-Zr crystals degrades gradually upon exposure to moisture. Thus, the internal $\mathrm{Si}$ and $\mathrm{P}$ atoms in polyoxoanions markedly affected the reactivity with zirconocene dichloride and the resulting stability toward moisture.

Elemental analysis of TBA-Si-Al-Zr dried overnight at room temperature under $10^{-3}-10^{-4}$ Torr of vacuum prior to analysis was consistent with the composition $\left[\left(n-\mathrm{C}_{4} \mathrm{H}_{9}\right)_{4} \mathrm{~N}\right]_{6}[\alpha-$ $\left.\mathrm{SiW}_{11} \mathrm{Al}(\mathrm{OH})_{2} \mathrm{O}_{38} \mathrm{ZrCp}\right]_{2} \cdot 2 \mathrm{H}_{2} \mathrm{O}$. The weight loss observed during the drying of TBA-Si-Al-Zr prior to analysis was $0.18 \%$, suggesting the absence of solvent molecules. This suggestion was also supported by the ${ }^{1} \mathrm{H}$ NMR spectrum, as shown in the Experimental section. A weight loss of $25.4 \%$ with exothermic points at $352.0{ }^{\circ} \mathrm{C}$ and $483.0{ }^{\circ} \mathrm{C}$ was observed from 17.5 to $500{ }^{\circ} \mathrm{C}$ in the TG/DTA performed under atmospheric conditions; calculations based on these data indicated the loss of six $\left[\left(n-\mathrm{C}_{4} \mathrm{H}_{9}\right)_{4} \mathrm{~N}\right]^{+}$(calcd. 19.7\%) and four cyclopentadienyl groups (calcd. $3.5 \%$ ) (total: $23.2 \%$ ).

X-ray structural analysis revealed that the polyoxoanion Si-Al-Zr is dimeric, containing two $\left\{\mathrm{SiW}_{11} \mathrm{AlO}_{40}\right\}$ units bridged by two "bent sandwich" $\mathrm{Cp}_{2} \mathrm{Zr}^{2+}$ fragments, as shown in Figure 1. Selected bond distances and angles around the $\mathrm{Zr}$ center in $\mathbf{S i}-\mathbf{A l}-\mathbf{Z r}$ are summarized in Table 1, and the bond valence sum (BVS) calculations of the $\mathrm{W}, \mathrm{Si}, \mathrm{Al}$, and $\mathrm{O}$ atoms (Table S1) are provided in the Supporting Information. Each Zr center was bound to 
the terminal $\mathrm{O}$ atoms of the $\mathrm{Al}$ and $\mathrm{W}$ sites and to the edge-sharing $\mathrm{O}$ atom of the $\mathrm{Al}-\mathrm{O}-\mathrm{W}$ linkage with 5-coordination geometry. The molecular structure of Si-Al-Zr was quite similar to that of P-Al-Zr; however, the $\mathrm{Al} \cdots \mathrm{Al}(5.47 \AA)$ distance was larger than that of the polyoxoanion P-Al-Zr (5.32 A), and the angles of the Al-O-Zr bond $\left(109.7^{\circ}\right)$, the O-Zr-O bond $\left(73.5^{\circ}\right)$, and the $\mathrm{W}-\mathrm{O}-\mathrm{Zr}$ bond $\left(163.6^{\circ}\right)$ were larger than those of the polyoxoanion P-Al$\mathrm{Zr}\left(105.3^{\circ}, 69.1^{\circ}\right.$, and $159.7^{\circ}$, respectively). Thus, the two $\left\{\mathrm{SiW}_{11} \mathrm{AlO}_{40}\right\}$ units were displaced from each other relative to those of the polyoxoanion P-Al-Zr.

The values of the bond valence sums (BVSs) for TBA-Si-Al-Zr [41-44], which were calculated based on the observed bond lengths, were in the range of $5.615-6.107$ (average 5.861) for the $11 \mathrm{~W}$ atoms, 4.067 for the one $\mathrm{Si}$ atom, 2.712 for the one $\mathrm{Al}$ atom, and in the range of $1.623-2.063$ (average 1.842) for the $38 \mathrm{O}$ atoms, excluding $\mathrm{O}(18)$ and $\mathrm{O}(21)$; these values were in reasonable agreement with the formal valences of $\mathrm{W}^{6+}, \mathrm{Si}^{4+}, \mathrm{Al}^{3+}$, and $\mathrm{O}^{2-}$, respectively (Table S1). The calculated BVS values of $\mathrm{O}(18)$ and $\mathrm{O}(21)$ at the Al-O-Zr and Al-O-W linkages were 1.033 and 1.249, respectively, suggesting that a pair of protons were bound to each of the two bridging $\mathrm{O}$ atoms between the $\mathrm{Al}$ and $\mathrm{Zr}$ atoms, and another pair of protons was bound to the two bridging $\mathrm{O}$ atoms between the $\mathrm{Al}$ and $\mathrm{W}$ atoms. From the potentiometric titration, three break points at 2, 3, and 4 equivalents of added base were observed, as shown in Figure S1. This result also supported the presence of four protons in Si-

\section{Al-Zr.}

The FTIR spectra acquired in the POM region of TBA-Si-Al-Zr and TBA-Si-Al from $\mathrm{KBr}$ disks of the compounds are presented in Figure 2. The IR spectrum of TBA-Si-Al-Zr (1012, 969, 921, 885, 799, 756, 733, and $\left.669 \mathrm{~cm}^{-1}\right)$ was different from that of TBA-Si-Al $(1006,960$, 916, 880, 799, and $740 \mathrm{~cm}^{-1}$ ). Specifically, a new band appeared at $669 \mathrm{~cm}^{-1}$, probably because of the formation of Zr-O linkages; this was observed at $631 \mathrm{~cm}^{-1}$ for TBA-P-Al-Zr [25]. A band assigned to the $\mathrm{Cp}$ ligands was clearly observed at $3121 \mathrm{~cm}^{-1}$. These results suggested that the $\eta^{5}$-cyclopentadienylzirconium fragments were coordinated to the $[\alpha-$ $\left.\mathrm{SiW}_{11}\left\{\mathrm{Al}\left(\mathrm{OH}_{2}\right)\right\} \mathrm{O}_{39}\right]^{5-}$ surface.

The cold-spray ionization mass (CSI-MS) spectrum of TBA-Si-Al-Zr in acetonitrile 
exhibited peaks at $m / z=3910.8$ and 7577.4 , as shown in Figure 3. These peaks were assigned to $\left.\quad\left[\left\{\left(n-\mathrm{C}_{4} \mathrm{H}_{9}\right)_{4} \mathrm{~N}\right\} 8 \mathrm{SiW}_{11} \mathrm{Al}(\mathrm{OH})_{2} \mathrm{O}_{38} \mathrm{ZrCp}_{2}\right\}_{2}\right]^{2+} \quad$ and $\quad[(n-$ $\left.\left.\left.\mathrm{C}_{4} \mathrm{H}_{9}\right)_{4} \mathrm{~N}\right\}_{7}\left\{\mathrm{SiW}_{11} \mathrm{Al}(\mathrm{OH})_{2} \mathrm{O}_{38} \mathrm{ZrCp} 2\right\}_{2}\right]^{+}$, respectively, clearly indicating that the dimeric structure of Si-Al-Zr was maintained in acetonitrile solution.

The solution ${ }^{27} \mathrm{Al}$ NMR spectra of TBA-Si-Al-Zr and TBA-Si-Al acquired at $25{ }^{\circ} \mathrm{C}$ in acetonitrile- $d_{3}$ are shown in Figures 4 and S2. TBA-Si-Al-Zr showed a signal at 15.5 ppm, which was shifted relative to that of TBA-Si-Al $\left(\delta\right.$ 16.0). The solid-state ${ }^{27} \mathrm{Al}$ NMR spectrum of TBA-Si-Al-Zr also showed a signal at $9.8 \mathrm{ppm}$, as shown in Figure S3. These results indicated that the $\eta^{5}$-cyclopentadienylzirconium fragment was grafted on the surface of Si-Al and that the two $\mathrm{Al}$ sites in the $\left\{\mathrm{SiW}_{11} \mathrm{AlO}_{40}\right\}$ unit were equivalent in both the solution and solid phases. The solution ${ }^{29} \mathrm{Si} \mathrm{NMR}$ spectrum was not obtained because of the low solubility of TBA-Si-Al-Zr in acetonitrile. The solid-state ${ }^{29} \mathrm{Si}$ NMR spectrum of TBA-Si-Al-Zr was quite noisy; however, a signal was observed at $-81.9 \mathrm{ppm}$ (Figure S4). This also confirmed that the two $\left\{\mathrm{SiW}_{11} \mathrm{AlO}_{40}\right\}$ units were equivalent.

The ${ }^{1} \mathrm{H}$ NMR spectrum (Figure 5a) of TBA-Si-Al-Zr obtained at $\sim 25{ }^{\circ} \mathrm{C}$ in acetonitrile- $d_{3}$ showed four signals at $6.69,6.64,6.63$, and $6.59 \mathrm{ppm}$, with an integrated intensity ratio of approximately $1: 1: 1: 1$; these peaks were shifted relative to those of $\mathrm{Cp}_{2} \mathrm{Zr}(\mathrm{OTf})_{2} \cdot \mathrm{THF}$ ( $\delta$ 6.52). No signal attributable to the $\mathrm{Cp}_{2} \mathrm{Zr}^{2+}(\delta 6.44)$ formed by the reaction of $\mathrm{Cp}_{2} \mathrm{ZrCl}_{2}$ with $\mathrm{AgBF}_{4}$ was observed in acetonitrile- $d_{3}$, suggesting that the $\mathrm{Cp}_{2} \mathrm{Zr}^{2+}$ fragments were not eliminated from the surface of $\left[\alpha-\mathrm{SiW}_{11}\left\{\mathrm{Al}\left(\mathrm{OH}_{2}\right)\right\} \mathrm{O}_{39}\right]^{5-}(\mathbf{S i}-\mathbf{A l})$. Four signals were observed in the ${ }^{13} \mathrm{C}$ NMR spectrum at 117.1, 117.0, 116.8, and 116.5 ppm (Figure 5b). In contrast, the solid-state ${ }^{13} \mathrm{C}$ NMR spectrum of TBA-Si-Al-Zr showed a signal at $116.2 \mathrm{ppm}$ that was ascribed to $\mathrm{Cp}$ ligands, as shown in Figure 6. Thus, the four $\mathrm{Cp}$ ligands were not equivalent in acetonitrile solution whereas they were equivalent in the solid phase.

(Insert Table 1 and Figures $1-6$ here)

3.2 Meerwein-Ponndorf-Verley (MPV) reduction of ketones with 2-propanol catalyzed by TBA-Si-Al-Zr and TBA-P-Al-Zr in homogeneous and heterogeneous systems 
First of all, the hydrogen-transfer reaction between cyclohexanone and 2-propanol at $80 \pm$ $2{ }^{\circ} \mathrm{C}$ catalyzed by TBA-Si-Al-Zr and TBA-P-Al-Zr was examined in a homogeneous system, as shown in Figure 7. The catalytic activities are summarized in Table 2. During the reduction reactions, all the catalysts in Table 2 were soluble in acetonitrile. Cyclohexanol and acetone were obtained with $>99 \%$ selectivity. No reaction was observed in the absence of a catalyst under the tested reaction conditions. A Brønsted acid catalyst, $\mathrm{H}_{3} \mathrm{PW}_{12} \mathrm{O}_{40} \cdot 23 \mathrm{H}_{2} \mathrm{O}$, also showed no reaction. The conversions involving both TBA-Si-Al-Zr and TBA-P-Al-Zr were $>99 \%$ complete after $24 \mathrm{~h}$ and both turnover numbers $(\mathrm{TON}=[\mathrm{mol}$ of cyclohexanol $] /[\mathrm{mol}$ of catalyst $]$ ) reached 280. As control experiments, TBA-Si-Al and $\left[\left(n-\mathrm{C}_{4} \mathrm{H}_{9}\right)_{4} \mathrm{~N}\right] 4[\alpha-$ $\left.\mathrm{PW}_{11}\left\{\mathrm{Al}\left(\mathrm{OH}_{2}\right)\right\} \mathrm{O}_{39}\right]$ (TBA-P-Al) showed no reaction within $24 \mathrm{~h}$. The conversions of $\mathrm{Cp}_{2} \mathrm{ZrCl}_{2}$ and a mixture of $\mathrm{Cp}_{2} \mathrm{ZrCl}_{2}$ and TBA-P-Al after $24 \mathrm{~h}$ were $1.7 \%$ and $0.95 \%$, respectively; this supported the result that TBA-P-Al-Zr was not obtained by a direct reaction of TBA-P-Al with $\mathrm{Cp}_{2} \mathrm{ZrCl}_{2}$, as mentioned above. In contrast, TBA-Si-Al-Zr was easily formed by the reaction of TBA-Si-Al with $\mathrm{Cp}_{2} \mathrm{ZrCl}_{2}$ in acetonitrile, and showed the high catalytic activities. Thus, the grafting reaction of $\mathrm{Cp}_{2} \mathrm{ZrCl}_{2}$ onto the mono-aluminumsubstituted site in TBA-Si-Al caused the effective active centers. Here, $\mathrm{Cp}_{2} \mathrm{Zr}(\mathrm{OTf})_{2} \cdot \mathrm{THF}$ showed faster initial rates, as shown in Figure S5. The conversion after $3 \mathrm{~h}$ was 29\%, exceeding those of TBA-Si-Al-Zr (18\%) and TBA-P-Al-Zr (20\%), and after $24 \mathrm{~h}$, the conversion was $82 \%$ (TON was 116). When TON was calculated on the basis of [mol of cyclohexanol]/[mol of zirconium atom], both TON after $24 \mathrm{~h}$ of TBA-Si-Al-Zr and TBA-PAl-Zr was 140, which was similar order to that of $\mathrm{Cp}_{2} \mathrm{Zr}(\mathrm{OTf})_{2} \cdot \mathrm{THF}$ (116). Thus, a clear effect of grafting reactions of $\mathrm{Cp}_{2} \mathrm{Zr}(\mathrm{OTf})_{2}$. THF onto the mono-aluminum-substituted sites in TBA-Si-Al-Zr and TBA-P-Al-Zr was not observed under the present reaction conditions.

However, TBA-Si-Al-Zr and TBA-P-Al-Zr can be used as heterogeneous catalysts because they are insoluble in 2-propanol; while, $\mathrm{Cp}_{2} \mathrm{Zr}(\mathrm{OTf})_{2} \cdot \mathrm{THF}$ is soluble in 2-propanol. The catalytic activities of TBA-Si-Al-Zr and TBA-P-Al-Zr in a heterogeneous system, i.e., in the absence of acetonitrile, were investigated for the MPV reduction of cyclohexanone, 
cyclopentanone, and 2-hexanone with 2-propanol at $80 \pm 2{ }^{\circ} \mathrm{C}$, as shown in Table 3 . For the all reactions, the corresponding alcohols and acetone were formed with $>99 \%$ selectively. For the reaction of cyclohexanone, the conversion after $24 \mathrm{~h}$ of TBA-Si-Al-Zr reached $>99 \%$; while, TBA-P-Al-Zr showed a low conversion (46\%). A numerous homogeneous and heterogeneous catalysts for MPV reduction have been reported $[45,46]$. Some of the recent examples containing aluminum and zirconium, $\mathrm{Cp}_{2} \mathrm{ZrH}_{2}$ [47], $\mathrm{ZrO}_{2}$ [48], zirconium 1propoxide grafted on SBA-15 [49], porous zirconium-phytic acid hybrid [50], partially crystalline zirconosilicate [51], [ $\left.\mathrm{CH}_{2}\left\{\mathrm{Me}\left(\mathrm{Me}_{3} \mathrm{Si}\right)_{2} \mathrm{Si}\right\}_{2} \mathrm{SiO}\right]_{2} \mathrm{AlOPr}\left(\mathrm{HOPr}^{\mathrm{i}}\right)[52], \quad \mathrm{Mg} / \mathrm{Al}$ and $\mathrm{Ca} / \mathrm{Al}$ mixed oxides $[53,54]$, and aluminum isopropoxide-grafted mesoporous organosilica [55], exhibited high conversions $(>80 \%)$ of cyclohexanone with 2-propanol under various reaction conditions. Although it is difficult to draw a simple comparison, the catalytic activities of TBA-Si-Al-Zr were by no means inferior to them in both homogeneous and heterogeneous system. TBA-Si-Al-Zr also showed the higher conversion (55\% after $96 \mathrm{~h}$ ) in the MPV reduction of cyclopentanone than that of TBA-P-Al-Zr (30\%). When 2-hexanone was used as a substrate, the conversion after $96 \mathrm{~h}$ of TBA-Si-Al-Zr decreased to 24\%, which was similar to that of TBA-P-Al-Zr (26\%).

After $24 \mathrm{~h}$ of reaction for cyclohexanone, the catalysts were collected using a membrane filter (JG $0.2 \mu \mathrm{m})$ and washed with a small amount of ethanol. No precipitation was formed by the addition of excess water to the filtrates, suggesting no leaching of TBA-Si-Al-Zr and TBA-P-Al-Zr into the reaction solutions. ${ }^{31} \mathrm{P}$ NMR spectrum in acetonitrile- $d_{3}$ of the filtrate of TBA-P-Al-Zr also showed no signals; this suggested that TBA-P-Al-Zr did not leach into the solutions. The FT-IR spectra of solid samples showed bands at $(1010,965,921,883,800$, 758 , and $\left.668 \mathrm{~cm}^{-1}\right)$ and $\left(1080,1065,969,888,810,786,749,703\right.$, and $\left.629 \mathrm{~cm}^{-1}\right)$, respectively, which were the same as those of as-prepared samples [25]. The ${ }^{31} \mathrm{P}$ NMR spectrum in acetonitrile- $d_{3}$ of a solid sample of TBA-P-Al-Zr also showed two signals at -12.25 and $12.35 \mathrm{ppm}$, which were the same as those of as-prepared sample [25]. No other signals were observed. These results suggested that the dimeric structures of TBA-Si-Al-Zr and TBA-PAl-Zr were maintained under the present reaction conditions. For the ${ }^{1} \mathrm{H}$ NMR spectrum in 
acetonitrile- $d_{3}$ of a sample of TBA-Si-Al-Zr, four signals assigned to Cp ligands were observed at $6.69,6.64,6.63$, and $6.59 \mathrm{ppm}$, which were the same as those of as-prepared sample (Figure S8a). The ${ }^{1} \mathrm{H}$ NMR spectrum of a sample of TBA-P-Al-Zr showed two signals of Cp ligands at 6.67 and $6.56 \mathrm{ppm}$, as shown in Figure S8b. The two signals were also the same as those of as-prepared sample [25]. Thus, the active centers would not be caused by cleavage of linkages between the two Keggin mono-aluminum-substituted units. When a solid sample of TBA-Si-Al-Zr was used as a catalyst in the second run for the MPV reduction of cyclohexanone with 2-propanol at $80 \pm 2{ }^{\circ} \mathrm{C}$, the conversion after $24 \mathrm{~h}$ was approximately 90\%, showing that TBA-Si-Al-Zr was basically recyclable. Further studies regarding the reaction mechanism including determination of the active centers are in progress and will be reported elsewhere.

(Insert Tables 2 and 3, and Figure 7 here)

\section{Conclusion}

The tetra-n-butylammonium salt of $\left[\alpha-\mathrm{SiW} 11 \mathrm{Al}(\mathrm{OH})_{2} \mathrm{O}_{38} \mathrm{ZrCp}_{2}\right]_{2}{ }^{6-} \quad(\mathbf{S i}-\mathbf{A l}-\mathrm{Zr}), \quad[(n-$ $\left.\left.\mathrm{C}_{4} \mathrm{H}_{9}\right)_{4} \mathrm{~N}\right]_{6}\left[\alpha-\mathrm{SiW}_{11} \mathrm{Al}(\mathrm{OH})_{2} \mathrm{O}_{38} \mathrm{ZrCp}_{2}\right]_{2} \cdot 2 \mathrm{H}_{2} \mathrm{O}$ (TBA-Si-Al-Zr), was obtained from a $1: 1$ stoichiometric reaction of $\left[\left(n-\mathrm{C}_{4} \mathrm{H}_{9}\right)_{4} \mathrm{~N}\right]_{4} \mathrm{~K}_{0.5} \mathrm{H}_{0.5}\left[\alpha-\mathrm{SiW}_{11}\left\{\mathrm{Al}\left(\mathrm{OH}_{2}\right)\right\} \mathrm{O}_{39}\right] \cdot \mathrm{H}_{2} \mathrm{O}$ (TBA-Si-Al) with $\mathrm{Cp}_{2} \mathrm{Zr}(\mathrm{OTf})_{2} \cdot \mathrm{THF}$ in acetonitrile solution under an $\mathrm{Ar}$ atmosphere, followed by precipitation from water and crystallization via vapor diffusion from acetonitrile/methanol in air. Single-crystal X-ray structure analysis of TBA-Si-Al-Zr revealed that the two $\left\{\mathrm{SiW}_{11} \mathrm{AlO}_{40}\right\}$ units are bridged by two "bent sandwich" $\mathrm{Cp}_{2} \mathrm{Zr}^{2+}$ fragments, in which the four $\eta^{5}$-cyclopentadienyl ligands were equivalent in the solid phase but not equivalent in acetonitrile solution. The molecular structure of Si-Al-Zr was quite similar to that of $[\alpha-$ $\left.\mathrm{PW}_{11} \mathrm{Al}(\mathrm{OH}) \mathrm{O}_{39} \mathrm{ZrCp}_{2}\right]_{2}{ }^{6-}$ (P-Al-Zr); however, the partial structures around $\mathrm{Al}$ and $\mathrm{Zr}$ centers, including the position and number of protons, and the dynamic behaviors of the four $\mathrm{Cp}$ ligands in acetonitrile solution were remarkably different from those of P-Zr-Al. TBA-Si-AlZr was also formed by a 1:1 stoichiometric reaction of TBA-Si-Al with $\mathrm{Cp}_{2} \mathrm{ZrCl}_{2}$ in air; this 
was different from that of $\left[\left(n-\mathrm{C}_{4} \mathrm{H}_{9}\right)_{4} \mathrm{~N}\right]_{6}\left[\alpha-\mathrm{PW}{ }_{11} \mathrm{Al}(\mathrm{OH}) \mathrm{O}_{39} \mathrm{ZrCp}_{2}\right]_{2}$ (TBA-P-Al-Zr). Furthermore, we investigated the catalytic activities of TBA-Si-Al-Zr and TBA-P-Al-Zr in the MPV reduction of cyclohexanone, cyclopentanone, and 2-hexanone with 2-propanol in both homogeneous and heterogeneous system. In a homogenous system, both compounds exhibited $>99 \%$ conversions after $24 \mathrm{~h}$ for the MPV reduction of cyclohexanone; thus, a clear effect of the internal atoms was not observed. In contrast, TBA-Si-Al-Zr exhibited the higher activities than those of TBA-P-Al-Zr for cyclohexanone and cyclopentanone in a heterogeneous system. FT-IR and ${ }^{31} \mathrm{P}$ NMR spectra showed that the dimeric structures of these compounds were maintained under the present reaction conditions. Thus, the direct reaction of $\mathrm{Cp}_{2} \mathrm{Zr}(\mathrm{OTf})_{2} \cdot \mathrm{THF}$ (or $\mathrm{Cp}_{2} \mathrm{ZrCl}_{2}$ ) with TBA-Si-Al-Zr caused the high catalytic activities for MPV reduction in both homogeneous and heterogeneous system.

\section{Acknowledgements}

This work was supported by a Grant-in-Aid for Scientific Research of the Ministry of Education, Culture, Sports, Science and Technology of Japan.

\section{References}

[1] M.T. Pope, Heteropoly and Isopoly Oxometalates (Springer-Verlag, Berlin, 1983).

[2] Pope MT, Müller A (1991) Angew Chem Int Ed Engl 30:34.

[3] Polyoxometalates: From Platonic Solids to Anti-Retroviral Activity, eds. M. T. Pope and A. Müller (Kluwer Academic Publishers, Dordrecht, The Netherlands, 1994).

[4] Wang S, Yang, G (2015) Chem Rev 115:4893.

[5] Dolbecq A, Dumas E, Mayer CR, Mialane P (2010) Chem Rev 110:6009.

[6] Dolbecq A, Mialane P, Sècheresse F, Keita B, Nadjo L (2012) Chem Commun 48:8299.

[7] Proust A, Thouvenot R, Gouzerh P (2008) Chem Commun 1837.

[8] Gouzerh P, Proust A (1998) Chem Rev 98:77.

[9] Day VW, Klemperer WG (1993) Mol Eng 3:61. 
[10] Day VW, Eberspacher TA, Klemperer WG, Planalp RP, Schiller PW, Yagasaki A, Zhong B (1993) Inorg Chem 32:1629.

[11] Day VW, Klemperer WG, Main DJ (1990) Inorg Chem 29:2345.

[12] Klemperer WG, Main DJ (1990) Inorg Chem 29:2355.

[13] Weiner H, Hayashi Y, Finke RG (1999) Inorg Chem 38:2579.

[14] Nomiya K, Mizuno N, Lyon DK, Phol M, Finke RG (1997) Inorg Synth 31:186.

[15] Lin Y, Nomiya K, Finke RG (1993) Inorg Chem 32:6040.

[16] Rapko BM, Pohl M, Finke RG (1994) Inorg Chem 33:3625, and reference therein.

[17] Yang L, Hou L, Ma P, Niu J (2013) J Coord Chem 66:1330.

[18] Laurencin D, Villanneau R, Gérard H, Proust A (2006) J Phys Chem A 110:6345.

[19] Artero V, Laurencin D, Villanneau R, Thouvenot R, Herson P, Gouzerh P, Proust A (2005) Inorg Chem 44:2826.

[20] Sakai Y, Shinohara A, Hayashi K, Nomiya K (2006) Eur J Inorg Chem 163.

[21] Nomiya K, Hayashi K, Kasahara Y, Iida T, Nagaoka Y, Yamamoto H, Ueno T, Sakai Y (2007) Bull Chem Soc Jpn 80:724.

[22] Kato CN, Morii Y, Hattori S, Nakayama R, Makino Y, Uno H (2012) Dalton Trans $41: 10021$

[23] Dupré N, Brazel C, Fensterbank L, Malacria M, Thourimbert S, Hasenknopf B, Lacôte E (2012) Chem Eur J 18:12962.

[24] Proust A, Matt B, Villanneau T, Guillemot G, Gouzerh P, Izzet G (2012) Chem Soc Rev 41:7605, and reference therein.

[25] Kato CN, Makino Y, Unno W, Uno H (2013) Dalton Trans 42:1129.

[26] Raith A, Altmann P, Cokoja M, Herrmann WA, Kühn FE (2010) Coord Chem Rev $254: 608$.

[27] Glöckner A, Tamm M (2013) Chem Soc Rev 42:128.

[28] Krut'ko DP (2009) Russ Chem Bull Int Ed 58:1745.

[29] Day VW, Earley CW, Klemperer WG, Maltbie DJ (1985) J Am Chem Soc 107:8261.

[30] Klemperer WG, Zhong B (1993) Inorg Chem 32:5821. 
[31] Radkov EV, Young VG Jr, Beer RH (1999) J Am Chem Soc 121:8953.

[32] Radkov EV, Beer RH (2000) Inorg Chim Acta 297:191.

[33] Che TM, Day VW, Francesconi LC, Klemperer WG, Main DJ, Yagasaki A, Yaghi OM (1992) Inorg Chem 31:2920.

[34] Day VW, Klemperer WG, Maltbie DJ (1985) Organometallics 4:104.

[35] Tézé A, Hervé G (1977) J Inorg Nucl Chem 39:999.

[36] Ma R, Wei T, Zhao C (2011) Huaxue Shiji 33:307.

[37] C.N. Kato, Y. Makino, M. Yamasaki, Y. Kataoka, Y. Kitagawa, M. Okumura, in: Advances in Crystallization Processes, eds. Y. Mastai (InTech, Croatia, 2012) ch.23.

[38] Weiner H, Aiken III JD, Finke RG (1996) Inorg Chem 35:7905.

[39] Sheldrick GM (2008) Acta Crystallogr A64:112.

[40] Spek AL (2009) Acta Crystallogr D65:148.

[41] Brown ID, Altermatt D (1985) Acta Crystallogr B41:244.

[42] Brown ID, Shannon RD (1973) Acta Crystallogr A29:266.

[43] Brown ID (1992) Acta Crystallogr B48:553.

[44] Brown ID (1996) J. Appl. Crystallogr 29:479.

[45] Cha JS (2006) Org. Proc. Develop. 10:1032.

[46] Chuah GK, Jaenicke S, Zhu YZ, Liu SH (2006) Curr Org Chem 10:1639.

[47] Ishii Y, Nakano T, Inada A, Kishigami Y, Sakurai K, Ogawa M (1986) J Org Chem $51: 240$.

[48] Komanoya T, Nakajima K, Kitano M, Hara M (2015) J Phys Chem 119:26540.

[49] Zhu Y, Jaenick S, Chuah GK (2003) J Catal 218:396.

[50] Song J, Zhou B, Zhou H, Wu L, Meng Q, Liu Z, Han B (2015) Angew Chem Int Ed 54: 9399.

[51] Li G, Fu WH, Wang YM (2015) Catal Commun 62:10.

[52] McNerney B, Whittlesey B, Cordes DB, Krempner C (2014) Chem A Eur J 20:14959.

[53] Mora M, Lo'pez MI, Jime'nez-Sanchidria'n C, Ruiz JR (2010) Catal Lett 136:192.

[54] Ruiz JR, Jime'nez-Sanchidria'n C, Hidalgo JM, Marinas JM (2006) J Mol Catal A 
246:190.

[55] Shylesha S, Kapoorb MP, Junejab LR, Samuela PP, Srilakshmic C, Singha AP (2009) J Mol Catal 310:118. 


\section{Figure captions}

Figure 1. Molecular structure of polyoxoanion Si-Al-Zr with atom numberings.

Figure 2. FTIR spectra in the polyoxoanion region $\left(1800-400 \mathrm{~cm}^{-1}\right)$, as acquired from $\mathrm{KBr}$ disk of (a) TBA-Si-Al and (b) TBA-Si-Al-Zr.

Figure 3. CSI-MS spectrum of the acetonitrile solution of TBA-Si-Al-Zr. Inset: spectra in the range of $\mathrm{m} / \mathrm{z} 3890-3930$ and $7550-7620$, and the calculated patterns for $[\{(n-$ $\left.\left.\left.\mathrm{C}_{4} \mathrm{H}_{9}\right)_{4} \mathrm{~N}\right\}{ }_{8}\left\{\mathrm{SiW}_{11} \mathrm{Al}(\mathrm{OH})_{2} \mathrm{O}_{38} \mathrm{ZrCp}_{2}\right\}_{2}\right]^{2+} \quad(\mathrm{m} / \mathrm{z} \quad 3910.8) \quad$ and $\quad[\{(n-$ $\left.\left.\left.\mathrm{C}_{4} \mathrm{H}_{9}\right)_{4} \mathrm{~N}\right\}{ }_{7}\left\{\mathrm{SiW}_{11} \mathrm{Al}(\mathrm{OH})_{2} \mathrm{O}_{38} \mathrm{ZrCp}_{2}\right\}_{2}\right]^{+}(\mathrm{m} / \mathrm{z}$ 7577.4).

Figure 4. ${ }^{27} \mathrm{Al}$ NMR spectra in acetonitrile- $d_{3}$ of (a) TBA-Si-Al and (b) TBA-Si-Al-Zr.

Figure 5. (a) ${ }^{1} \mathrm{H}$ NMR and (b) ${ }^{13} \mathrm{C}$ NMR spectra in acetonitrile- $d_{3}$ of TBA-Si-Al-Zr.

Figure 6. Solid-state ${ }^{13} \mathrm{C}$ NMR spectrum of TBA-Si-Al-Zr.

Figure 7. Time course for the Meerwein-Ponndorf-Verley reduction of cyclohexanone with 2-propanol catalyzed by (a) TBA-Si-Al-Zr and (b) TBA-P-Al-Zr. Reaction conditions: see Table 2. 
Table 1 Selected bond distances and angles around zirconium and aluminum sites in TBA-SiAl-Zr

\begin{tabular}{llll}
\hline \multicolumn{4}{c}{ distances $(\AA)$} \\
\hline $\mathrm{Al}(1)-\mathrm{O}(4)$ & $1.865(11)$ & $\mathrm{W}(1)-\mathrm{O}(1)$ & $1.748(10)$ \\
$\mathrm{Al}(1)-\mathrm{O}(17)$ & $2.035(10)$ & $\mathrm{W}(1)-\mathrm{O}(2)$ & $1.919(12)$ \\
$\mathrm{Al}(1)-\mathrm{O}(18)$ & $1.873(9)$ & $\mathrm{W}(1)-\mathrm{O}(4)$ & $1.831(10)$ \\
$\mathrm{Al}(1)-\mathrm{O}(20)$ & $1.948(10)$ & $\mathrm{W}(1)-\mathrm{O}(5)$ & $2.035(9)$ \\
$\mathrm{Al}(1)-\mathrm{O}(21)$ & $1.903(11)$ & $\mathrm{W}(1)-\mathrm{O}(6)$ & $1.949(11)$ \\
$\mathrm{Al}(1)-\mathrm{O}(29)$ & $1.885(11)$ & $\mathrm{W}(1)-\mathrm{O}(7)$ & $2.060(10)$ \\
$\mathrm{Zr}(1)-\mathrm{O}(1)$ & $2.230(10)$ & $\mathrm{W}(4)-\mathrm{O}(17)$ & $2.397(9)$ \\
$\mathrm{Zr}(1)-\mathrm{O}(18)^{1}$ & $2.164(10)$ & $\mathrm{W}(4)-\mathrm{O}(19)$ & $1.930(11)$ \\
$\mathrm{Zr}(1)-\mathrm{O}(20)^{1}$ & $2.239(9)$ & $\mathrm{W}(4)-\mathrm{O}(20)$ & $1.933(8)$ \\
$\mathrm{Si}(1)-\mathrm{O}(17)$ & $1.635(10)$ & $\mathrm{W}(4)-\mathrm{O}(22)$ & $1.715(11)$ \\
$\mathrm{Zr}(1) \cdots \mathrm{Zr}(1)$ & $7.950(3)$ & $\mathrm{W}(4)-\mathrm{O}(30)$ & $1.916(10)$ \\
$\mathrm{Al}(1) \cdots \mathrm{Al}(1)$ & $5.465(5)$ & $\mathrm{W}(4)-\mathrm{O}(31)$ & $1.959(10)$ \\
$\mathrm{Zr}(1)-\mathrm{centroid} \mathrm{Cp}(1-5)$ & 2.273 & & \\
$\mathrm{Zr}(1)-\mathrm{centroid} \mathrm{Cp}(6-10)$ & 2.264 & $\mathrm{~W}(1)-\mathrm{O}(1)-\mathrm{Zr}(1)$ & $163.5(6)$ \\
\hline \multicolumn{5}{c}{ angles $\left({ }^{\circ}\right)$} \\
$\mathrm{Al}(1)-\mathrm{O}(18)-\mathrm{Zr}(1)^{1}$ & $109.7(5)$ & $\mathrm{W}(1)-\mathrm{O}(4)-\mathrm{Al}(1)$ & $145.3(6)$ \\
$\mathrm{O}(1)-\mathrm{Zr}(1)-\mathrm{O}(18)^{1}$ & $73.5(4)$ & $\mathrm{O}(1)-\mathrm{W}(1)-\mathrm{O}(4)$ & $100.7(5)$ \\
$\mathrm{O}(18)-\mathrm{Al}(1)-\mathrm{O}(20)$ & $79.1(4)$ & & \\
$\mathrm{Cp}(1-5)-\mathrm{Zr}(1)-\mathrm{Cp}(6-10)$ & 128.92 & & \\
\hline $\mathrm{ISym}$ & & &
\end{tabular}

${ }^{1}$ Symmetry operator: (1) $-\mathrm{X}+1 / 2+1,-\mathrm{Y}+1 / 2+1,-\mathrm{Z}+1$ 
Table 2 Meerwein-Ponndorf-Verley reduction of cyclohexanone with 2-propanol in a homogeneous system ${ }^{\mathrm{a}}$

\begin{tabular}{|c|c|c|c|c|}
\hline catalyst $(\mu \mathrm{mol})$ & reaction time $(\mathrm{h})$ & selectivity of cyclohexanol (\%) & $\mathrm{TON}^{\mathrm{b}}$ & conversion $(\%)^{\mathrm{c}}$ \\
\hline \multirow[t]{2}{*}{ TBA-Si-Al-Zr (6.8) } & 3 & $>99$ & 51 & 18 \\
\hline & 24 & $>99$ & 280 & $>99$ \\
\hline \multirow[t]{2}{*}{ TBA-P-Al-Zr (6.8) } & 3 & $>99$ & 57 & 20 \\
\hline & 24 & $>99$ & 280 & $>99$ \\
\hline \multirow[t]{2}{*}{$\mathrm{Cp}_{2} \mathrm{Zr}(\mathrm{OTf})_{2} \cdot \mathrm{THF}(13.5)$} & 3 & $>99$ & 40 & 29 \\
\hline & 24 & $>99$ & 116 & 82 \\
\hline $\mathrm{Cp}_{2} \mathrm{ZrCl}_{2}(13.7)$ & 24 & $>99$ & 2.3 & 1.7 \\
\hline A mixture of TBA-P-Al (13.5) and $\mathrm{Cp}_{2} \mathrm{ZrCl}_{2}$ (13.7) & 24 & $>99$ & $1.3^{\mathrm{d}}$ & 0.95 \\
\hline TBA-Si-Al (6.7) & 24 & - & - & - \\
\hline TBA-P-Al (6.8) & 24 & - & - & - \\
\hline
\end{tabular}

${ }^{\mathrm{a}}$ Reaction conditions: catalyst $(6.7-13.7 \mu \mathrm{mol})$, cyclohexanone $(1.9 \mathrm{mmol})$, 2-propanol $(13 \mathrm{mmol})$, acetonitrile $(4 \mathrm{~mL})$, reaction temperature $80 \pm 2{ }^{\circ} \mathrm{C}$, under argon.

${ }^{\mathrm{b}}$ Turnover number $(\mathrm{TON})=[\mathrm{mol}$ of cyclohexanol $] /[\mathrm{mol}$ of catalyst $]$.

${ }^{\mathrm{c}}$ Conversion $(\%)=\left\{[\mathrm{mol} \text { of cyclohexanone }]_{0}-[\mathrm{mol} \text { of cyclohexanone }]_{t}\right\} /[\mathrm{mol} \text { of cyclohexanone }]_{0} \times 100$.

${ }^{\mathrm{d}} \mathrm{TON}$ was calculated on the basis of mol of TBA-P-Al. 
Table 3 Meerwein-Ponndorf-Verley reduction of ketones with 2-propanol in a heterogeneous system ${ }^{\text {a }}$

\begin{tabular}{|c|c|c|c|c|c|}
\hline substrate (mmol) & catalyst & reaction time $(\mathrm{h})$ & selectivity of product (\%) & $\mathrm{TON}^{\mathrm{b}}$ & conversion $(\%)^{\mathrm{c}}$ \\
\hline \multirow[t]{2}{*}{ cyclohexanone (1.9) } & TBA-Si-Al-Zr & 24 & cyclohexanol $(>99)$ & 70 & $>99$ \\
\hline & TBA-P-Al-Zr & 24 & cyclohexanol (>99) & 33 & 46 \\
\hline \multirow[t]{2}{*}{ cyclopentanone (2.2) } & TBA-Si-Al-Zr & 96 & cyclopentanol (>99) & 45 & 55 \\
\hline & TBA-P-Al-Zr & 96 & cyclopentanol (>99) & 24 & 30 \\
\hline \multirow[t]{2}{*}{ 2-hexanone (1.6) } & TBA-Si-Al-Zr & 96 & 2-hexanol (>99) & 14 & 24 \\
\hline & TBA-P-Al-Zr & 96 & 2-hexanol (>99) & 15 & 26 \\
\hline
\end{tabular}

${ }^{\mathrm{a}}$ Reaction conditions: catalyst $(27 \mu \mathrm{mol})$, substrates $(1.6-2.2 \mathrm{mmol}), 2$-propanol $(78 \mathrm{mmol})$, reaction temperature $80 \pm 2{ }^{\circ} \mathrm{C}$, under argon.

${ }^{\mathrm{b}}$ Turnover number $(\mathrm{TON})=[\mathrm{mol}$ of corresponding alcohol $] /[$ mol of catalyst $]$.

${ }^{\mathrm{c}}$ Conversion $(\%)=\left\{[\text { mol of substrate }]_{0}-[\text { mol of substrate }]_{t}\right\} /[\text { mol of substrate }]_{0} \times 100$. 


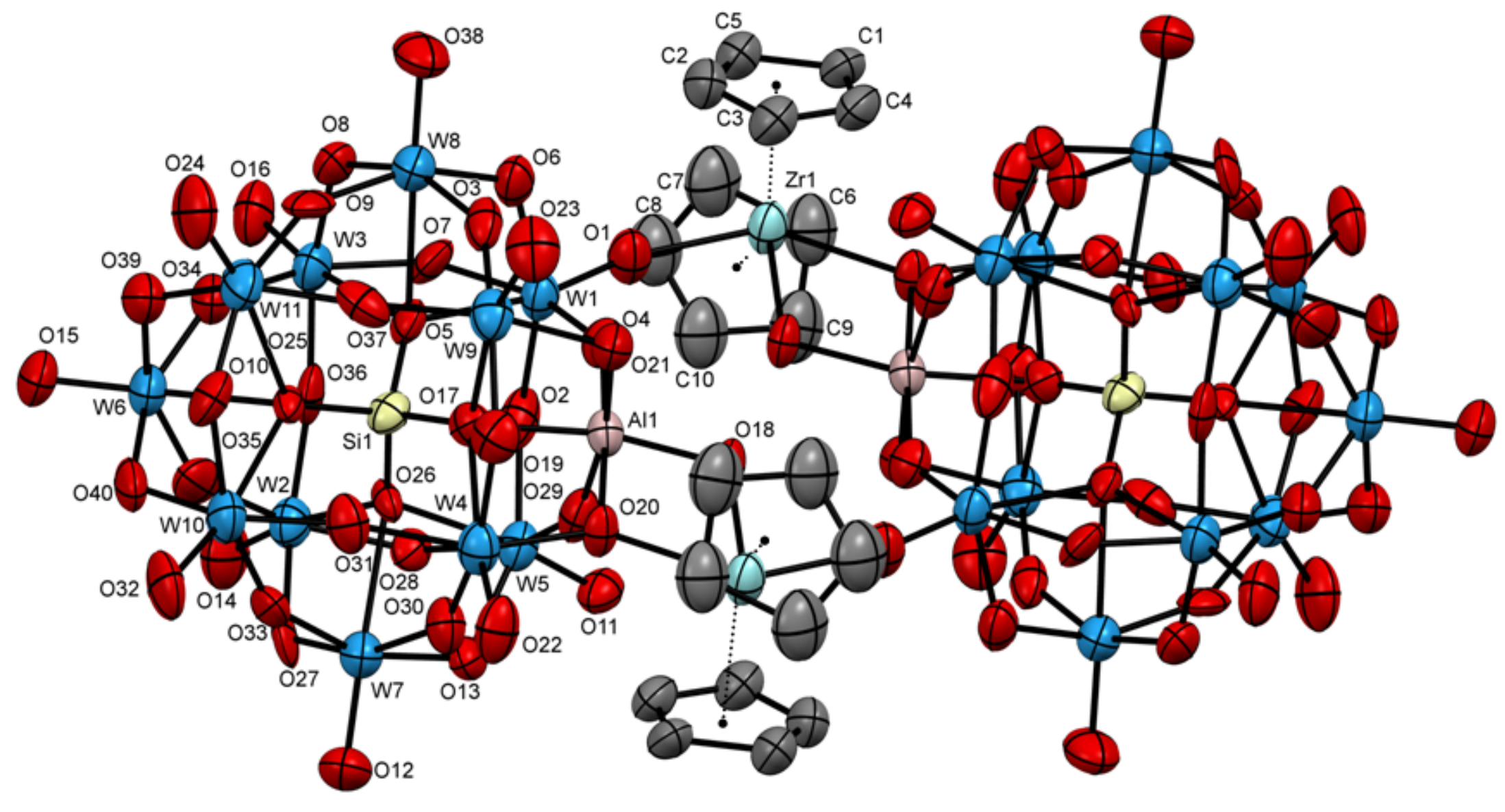

Figure 1 
(a)

(b)
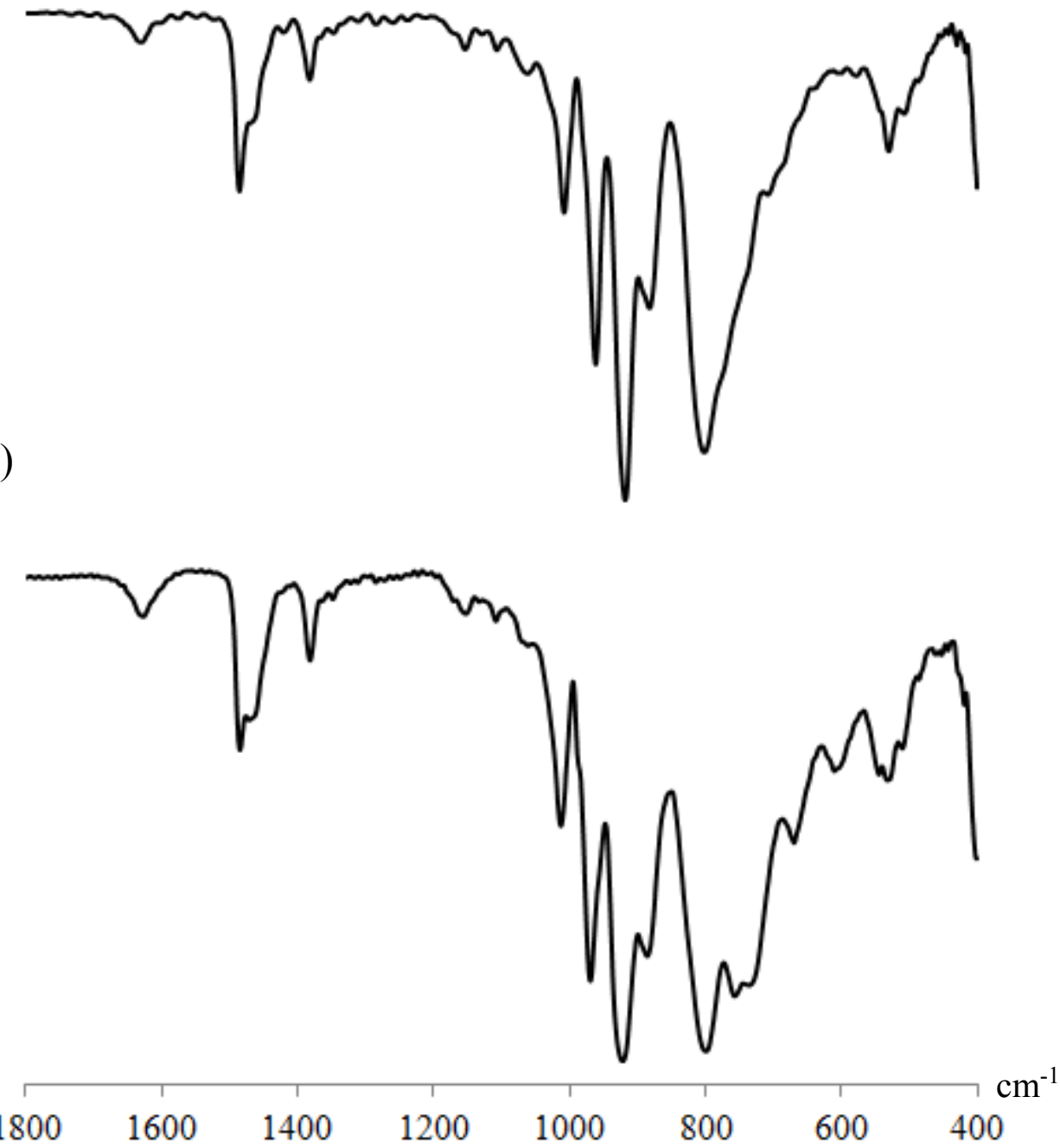

Figure 2 


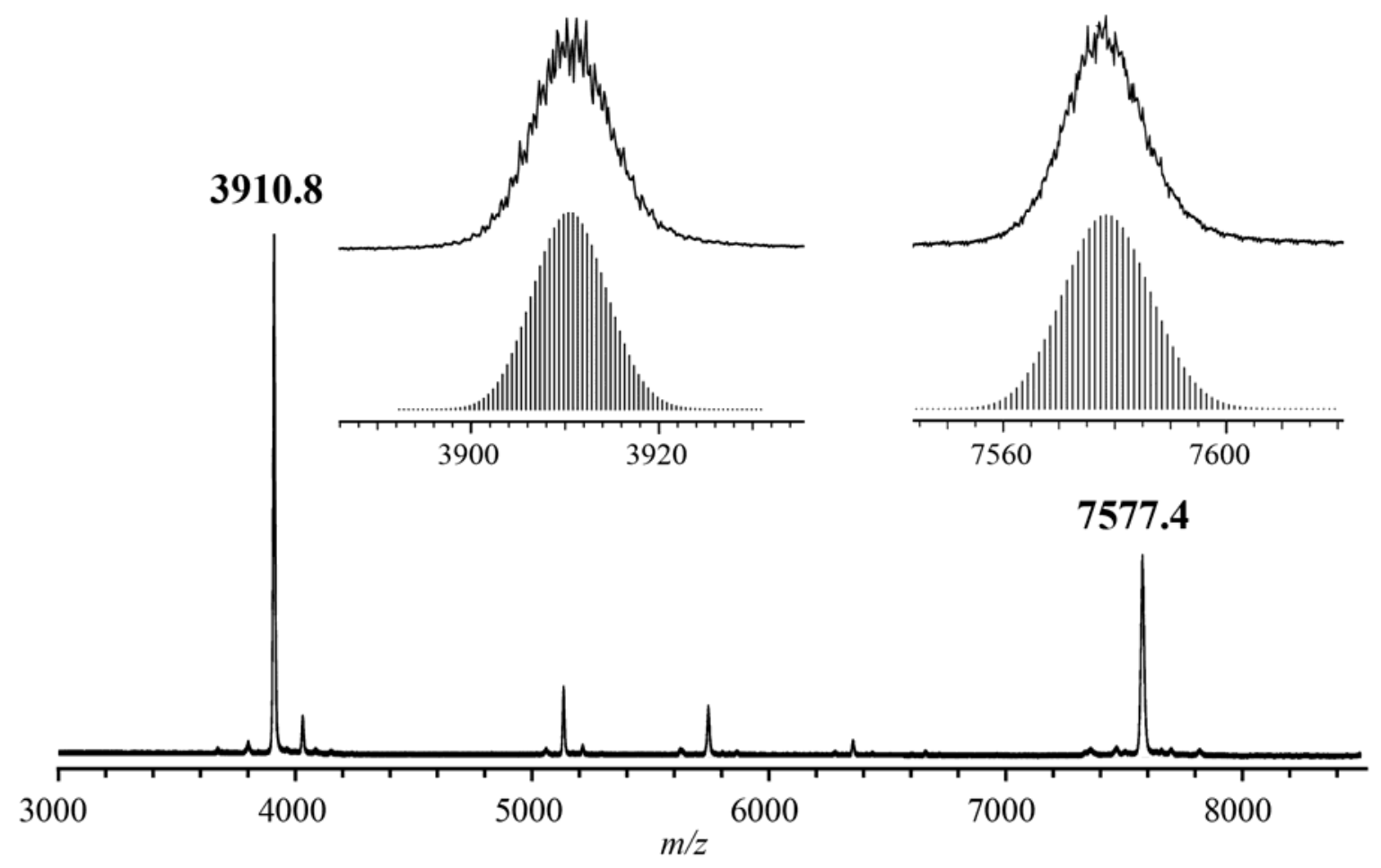

Figure 3 

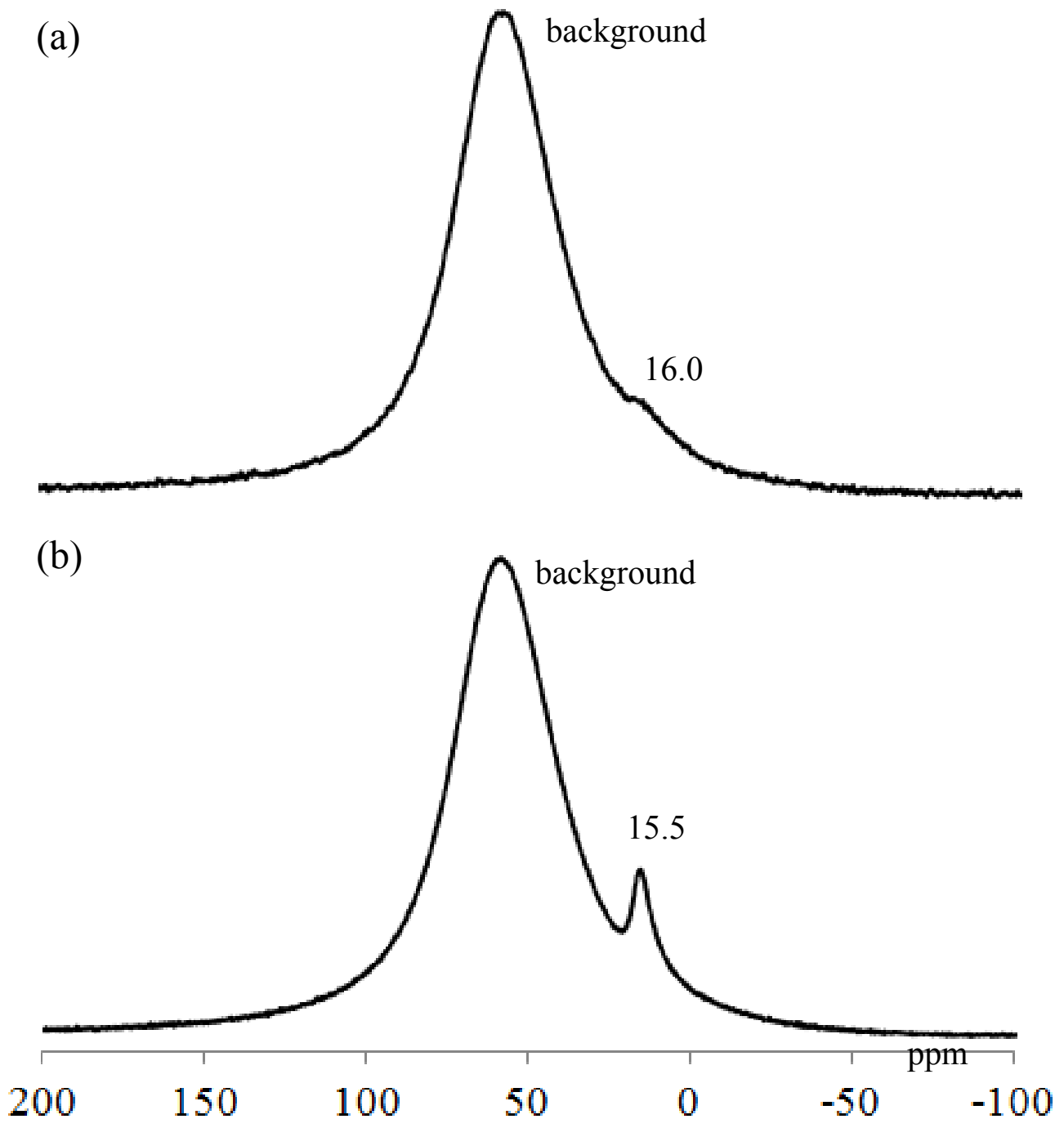

Figure 4 

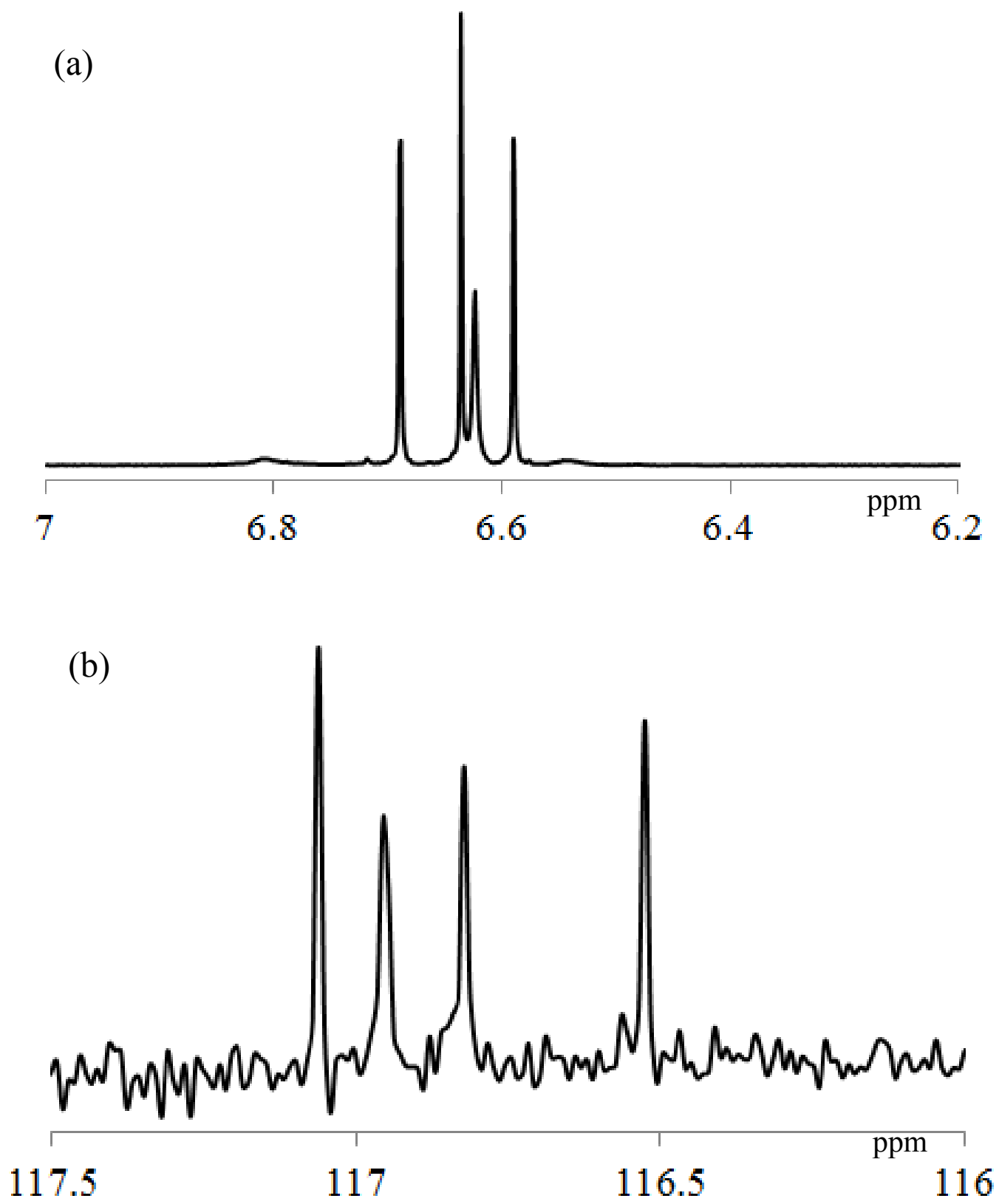

Figure 5 


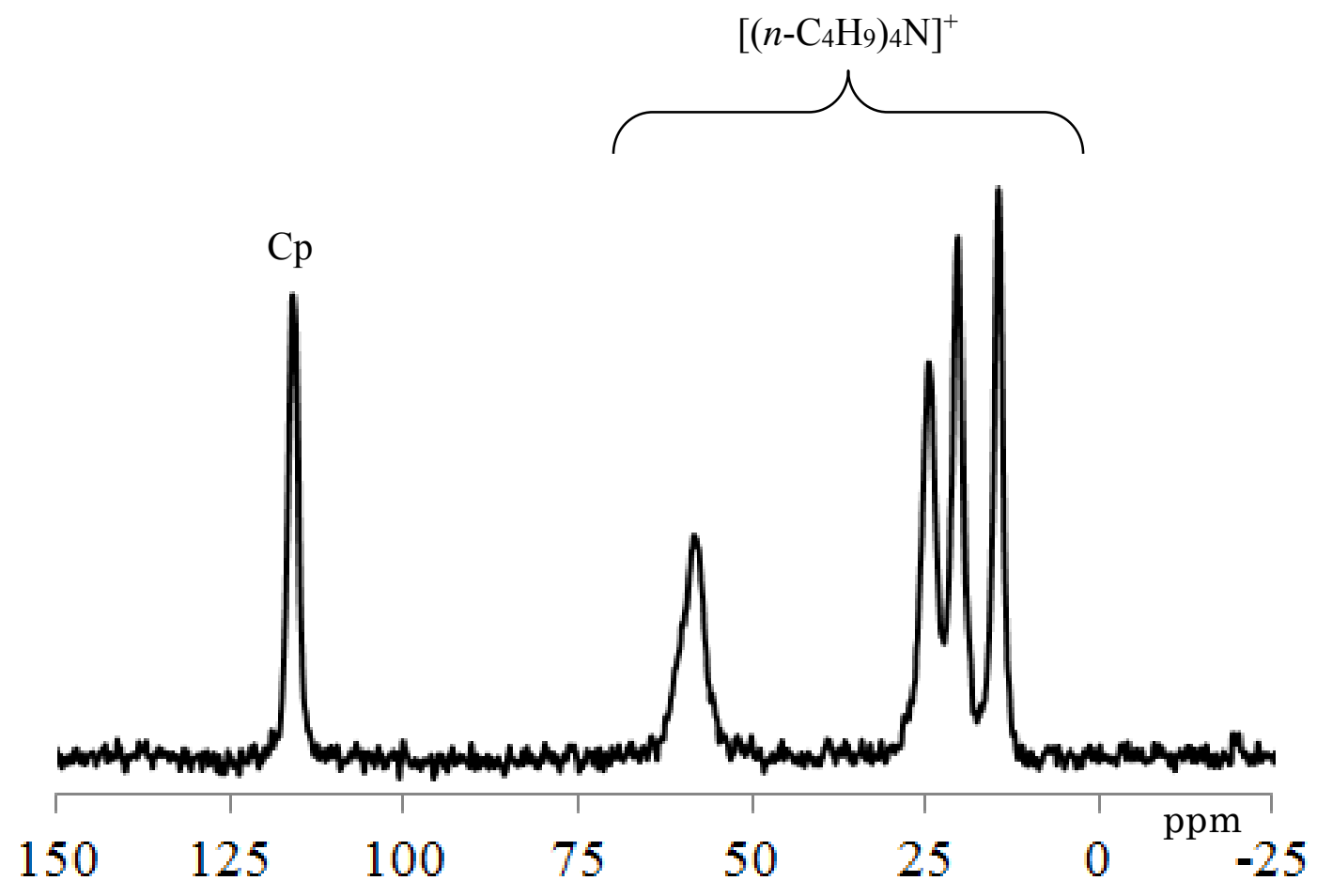

Figure 6 

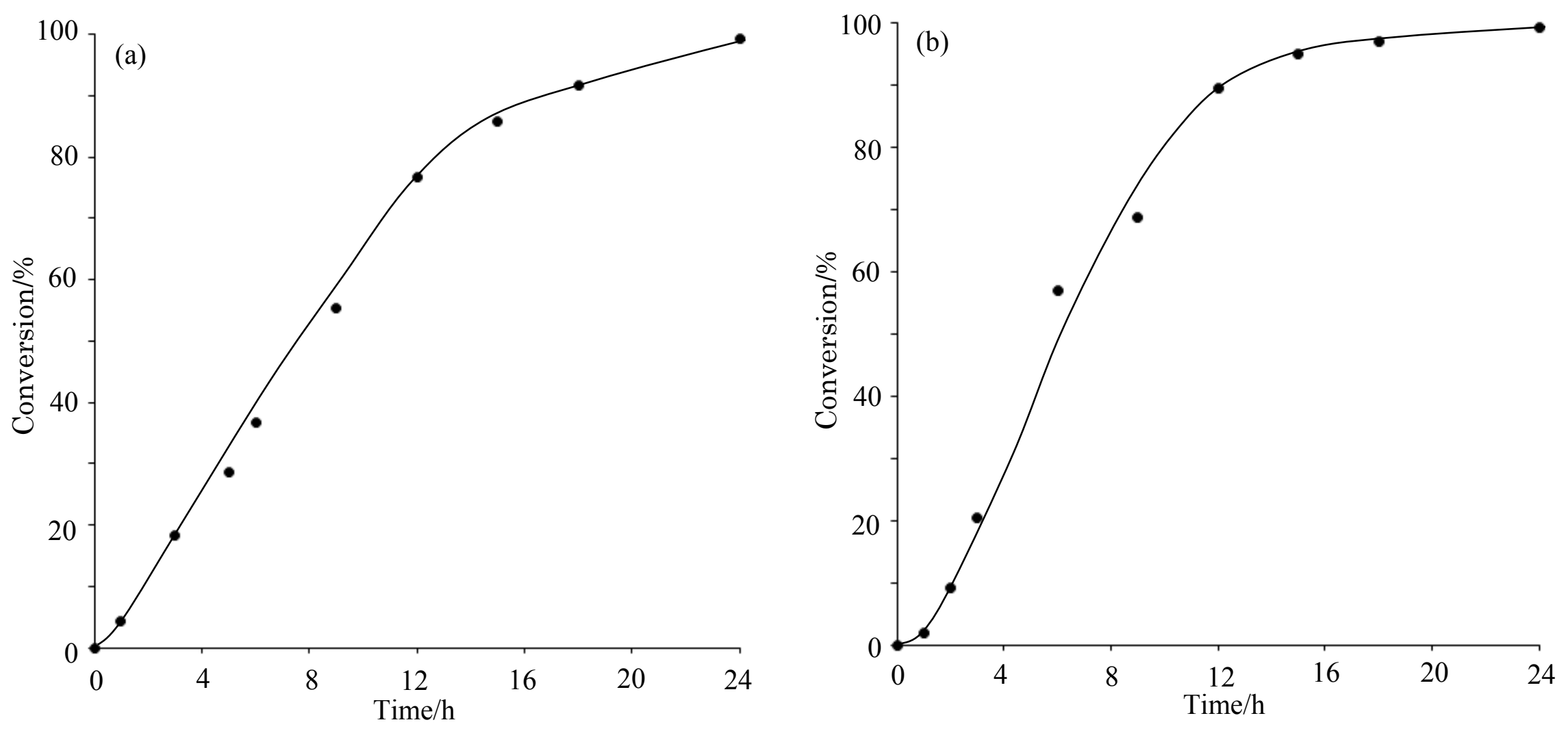

Figure 7 